\title{
Tinnitus and its relationship with anxiety and depression in the elderly: a systematic review
}

\author{
Paula Carolina Dias Gibrin ${ }^{1}$ \\ https://orcid.org/0000-0001-8354-4967 \\ Daiane Soares de Almeida Ciquinato ${ }^{1}$ \\ https://orcid.org/0000-0002-3280-7218 \\ Isabela Caroline Gonçalves ${ }^{1}$ \\ https://orcid.org/0000-0001-6633-3914 \\ Vitória de Moraes Marchiori² \\ https://orcid.org/0000-0001-6905-3950 \\ Luciana Lozza de Moraes Marchiori' \\ https://orcid.org/0000-0002-9026-0468
}

Pitágoras - Unopar, Londrina, Paraná, Brasil.

2 Universidade Vale do Itajai - Univali, Itajaí, Santa Catarina, Brasil.

Conflict of interests: Nonexistent

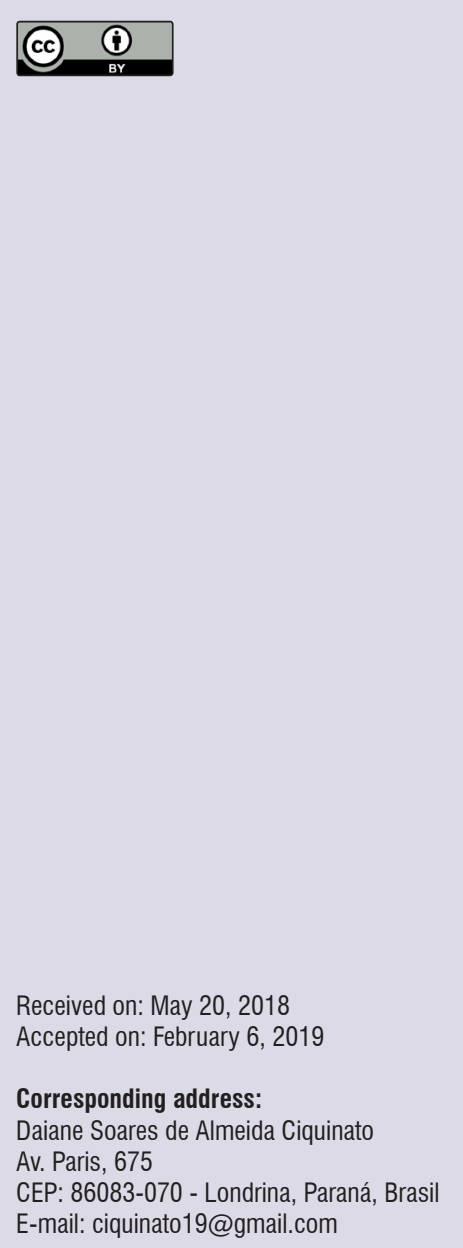

\section{ABSTRACT}

Objective: to verify, in the literature, a probable association of tinnitus with anxiety and depression in the elderly.

Methods: a systematic review (through a search in the indexed databases - Lilacs, Scielo, Pubmed, Science Direct, The Cochrane Library) of studies published between 2013 and 2018, in Portuguese and in English, involving adults and/or elderly (18 years and older). The descriptors used were: "tinnitus", "depression", "anxiety", "adult", "elderly", interspersed by the Boolean operator AND.

Results: 11 studies were selected, from which, 5 compared adults to elderly and only 2 evaluated such relationship in the elderly alone. Studies suggest that, as age increases, tinnitus severity and psychological symptoms also increase, affecting both men and women.

Conclusion: few studies compared the relationship between the variables among the elderly. A probable association between the variables for both genders has been found, suggesting that the advancing age contributes to the increase of tinnitus severity and its psychological symptoms, affecting the quality of life of these individuals. Further studies are suggested to confirm the association between tinnitus, anxiety and depression in the elderly. Multi-professional work is important for the evaluation and treatment of these people.

Keywords: Tinnitus; Anxiety; Depression; Adult; Aged 


\section{INTRODUCTION}

Tinnitus is a common symptom that may become debilitating. It can be described as the conscious perception of a sensation in the absence of an external stimulus ${ }^{1}$. This sensation is often related to the sounds of sizzle, rain, whistle or waterfall and may be distinct from person to person, being either continuous or intermittent ${ }^{2}$.

In the adult population in general, the prevalence of tinnitus is estimated to be between $10-15 \%^{3,4}$. This prevalence increases to $33-51 \%$ among individuals over 60 years of age $\mathrm{e}^{4-7}$, and this age group is the most affected by tinnitus. Brazilian studies agree with the prevalence presented in studies conducted in other countries ${ }^{4-8}$. This symptom, present in about 25 million Brazilians, affects the auditory pathways and may have several causes, such as primarily otologic diseases, or diseases that affect the ear secondarily, such as metabolic, cardiovascular, neurological, pharmacological, dental and psychiatric disorders ${ }^{8}$.

Mental disorders are characterized as a group of diseases with a high degree of overload, among them, depression and anxiety. Depression, of insidious origin, is characterized by loss of interest and pleasure in everything, by the feeling of sadness and low selfesteem, possibly leading, in the more severe cases, to suicide $^{9}$. Anxiety, in its turn, is a vague and unpleasant feeling of fear and apprehension, characterized by tension or discomfort derived from anticipating danger coming from either a known or unknown source. Anxiety and fear become recognized as pathological when they are exaggerated, disproportionate to the stimulus, or qualitatively different from what is observed as normal in that age group, thus interfering with the quality of life, emotional comfort or daily performance of the individual ${ }^{10}$.

Individuals with chronic tinnitus and nuisance often have associated psychological disorders, such as difficulty to concentrate and sleep, stress, irritability, anxiety and depression ${ }^{11}$. The prevalence of people who are troubled by tinnitus is $64 \%$, and in $18 \%$ of these patients, they report that tinnitus interferes with daily activities ${ }^{4}$. Authors indicate that there is a high degree of correlation between severe tinnitus and symptoms of depression and anxiety, but the results are not homogeneous ${ }^{5,10,11}$.

Recent systematic reviews ${ }^{12-14}$ have addressed the theme in a broad way, presenting this probable association in general, but they do not identify the results by age group. As previously shown, the highest prevalence of tinnitus is centered in the elderly population, and thus, considering the changes resulting from the aging process, a careful investigation directed to this population is made necessary. Thus, the main objective of this study was to systematically review in literature the likely association of tinnitus with anxiety and depression in the elderly and to identify differences from adult to elderly populations, if any is found.

\section{METHODS}

As a research strategy, it has been decided to carry out a review in literature on a probable association of tinnitus with anxiety and depression in the elderly. The work design was based on the national ${ }^{15}$ and international recommendations ${ }^{16}$ for the development of systematic reviews. The following guiding questions were elaborated in the first stage of the study: Is there a probable association of tinnitus with anxiety and depression in the elderly? Are there differences in the studies that approach adults and the elderly in relation to those that approach only the elderly as it refers to the results of the research?

In order to select the studies, a bibliographical survey of texts published in the period from 2013 to 2018 in electronic databases Lilacs, Scielo, Pubmed, Science Direct and The Cochrane Library was carried out. Based on the guiding question, the descriptors for the search were defined according to Decs - Descriptors in Health Sciences - and Mesh Terms, namely: "zumbido" (tinnitus), "depressão" (depression), "ansiedade" (anxiety), "adulto" (adult), "idoso" (elderly), interspersed by the Boolean operator "AND". The combination of the words used for the search was as follows: buzz AND depression; tinnitus AND anxiety; tinnitus AND depression AND adult; tinnitus AND depression AND elderly; tinnitus AND anxiety AND adult; tinnitus AND anxiety AND elderly. These combinations were used both in Portuguese and In English.

The inclusion criteria were: being an original research article; being complete work and fully available; having been published within the last five years in Portuguese or in English; including adults (age equal to or older than 18 years) and/or elderly (age equal to or older than 60 ), i.e., including both adults and elderly or only the elderly. The exclusion criteria were defined as: articles not related to the objective; duplicate work in databases; works that dealt with a specific population (Meniere's disease, deafness, malignant neoplasia, hyperacusis, war veterans, temporo-mandibular joint diseases, among others); language other than those 
of the inclusion criteria; articles expressing experts' opinions, letters to the editor and case reports, as well as articles that, after thoroughly reading the text, did not answer the guiding question.

The process of analyzing the articles was done in three stages. The first constituted in reading the titles and abstracts and selecting them according to the inclusion criteria. The second stage occurred with the thorough reading of the articles, in search of the answer to the guiding question. And the third step was performed through the critical analysis of selected articles. For this purpose, the NIH Quality Assessment Tool for Observational Cohort and Cross-sectional studies $^{17}$ was used for cohort and cross-sectional studies. Those classified as "good" and "fair" were included in the study. The selection of the works was done by two independent evaluators (P.C.D.G and D.S.A.C), and in case of conflict between them, a third evaluator was called (L.L.M.M) to settle the issue by consensus between them.

For this end, an instrument developed by the authors was used to extract data (I.C.G., P.C.D.G; V. M. M.) and to identify the works eligible for the study. This instrument included data such as: authors, study type, sample characterization, tinnitus evaluation, depression or anxiety assessment, objective and main results

\section{LITERATURE REVIEW}

The search found 354 matches. Studies not related to the objective were excluded ( $n=218$ ), as well as duplicates $(n=93)$, studies that did not include the elderly in its sample $(n=19)$, those dealing with a specific population as described in the methods $(n=8)$ and those that were in the language restriction category $(n=5)$. After thoroughly reading the articles, 11 studies were selected for this review. The identification and characteristics of the included studies are presented in Figure 1. The instruments used for evaluation of both tinnitus and depression and anxiety varied according to the authors' objective and are shown in the same figure.

The findings of this study should be interpreted with caution, as there are some limitations such as the restriction of foreign language, since four articles published in German and one in Chinese were excluded because only their abstracts were presented in English. In addition, few studies had been found that evaluated the theme in the elderly population.

\begin{tabular}{|c|c|c|c|c|c|}
\hline $\begin{array}{c}\text { Author and } \\
\text { year }\end{array}$ & Type of study & Sample & $\begin{array}{l}\text { Assessment } \\
\text { instruments* }\end{array}$ & Objective & Main results \\
\hline $\begin{array}{c}\text { Bhatt et al. } \\
(2016)^{18}\end{array}$ & $\begin{array}{l}\text { Cross- } \\
\text { sectional }\end{array}$ & $\begin{array}{l}21,467,314 \text { adult par- } \\
\text { ticipants aged } 18 \text { or } \\
\text { over. }\end{array}$ & $\begin{array}{l}\text { National health } \\
\text { research } \\
\text { questionnaire }\end{array}$ & $\begin{array}{l}\text { Quantify the relationship } \\
\text { between tinnitus, an- } \\
\text { xiety and depression in } \\
\text { adults. }\end{array}$ & $\begin{array}{l}\text { There is a strong association between tinnitus, } \\
\text { depression and anxiety. This association is } \\
\text { also strongly related to the severity of tinnitus } \\
\text { and the probability of anxiety and/or depres- } \\
\text { sion. }\end{array}$ \\
\hline $\begin{array}{l}\text { Trevis et al. } \\
(2016)^{19}\end{array}$ & $\begin{array}{l}\text { Cross- } \\
\text { sectional }\end{array}$ & $\begin{array}{l}81 \text { participants with } \\
\text { chronic tinnitus; age } \\
\text { ranging from } 18 \text { to } \\
82 \text { years, averaging } \\
44.6 \pm 16.2 \text { years. }\end{array}$ & $\begin{array}{l}\text { Tinnitus Case } \\
\text { Sample History } \\
\text { Questionnai-re; } \\
\text { THI; } \\
\text { STRAIT; BDI. }\end{array}$ & $\begin{array}{l}\text { Identify the } \\
\text { psychological } \\
\text { mediators of the vicious } \\
\text { cycle proposed for the } \\
\text { maintaining of the per- } \\
\text { ception of chronic tin- } \\
\text { nitus. }\end{array}$ & $\begin{array}{l}\text { Depressive symptoms act directly in maintai- } \\
\text { ning the perception of tinnitus and explain the } \\
\text { relationship between tinnitus and anxiety. }\end{array}$ \\
\hline $\begin{array}{l}\text { Weidt et al. } \\
(2016)^{20}\end{array}$ & $\begin{array}{l}\text { Cross- } \\
\text { sectional }\end{array}$ & $\begin{array}{l}208 \text { participants with } \\
\text { tinnitus; age ranging } \\
\text { from } 18 \text { to } 87 \text { years, } \\
\text { averaging } 46.8 \pm 14 \\
\text { years. }\end{array}$ & $\begin{array}{l}\text { THI; HRQoL; } \\
\text { BDI. }\end{array}$ & $\begin{array}{l}\text { Evaluate the associa- } \\
\text { tions between tinnitus, } \\
\text { quality of life, depressi- } \\
\text { ve symptoms, subjec- } \\
\text { tive noise intensity of } \\
\text { tinnitus and audiometric } \\
\text { characteristics. }\end{array}$ & $\begin{array}{l}\text { Depressive symptoms were significantly gre- } \\
\text { ater in patients with tinnitus, as compared } \\
\text { to the general population; severity of tinnitus } \\
\text { was positively associated with the depressive } \\
\text { symptoms. Quality of life was significantly lo- } \\
\text { wer in patients with tinnitus, when compared } \\
\text { to healthy control groups. }\end{array}$ \\
\hline $\begin{array}{l}\text { Wallhäusser- } \\
\text { Franke et al. } \\
(2017)^{21}\end{array}$ & $\begin{array}{l}\text { Cross- } \\
\text { sectional }\end{array}$ & $\begin{array}{l}57 \text { participants with } \\
\text { acute tinnitus; age } \\
\text { between } 21 \text { and } 79 \\
\text { years, averaging } \\
41.4 \pm 15.6 \text { years. }\end{array}$ & $\begin{array}{l}\text { Mini-TQ12; } \\
\text { PHQ9; } \\
\text { GAD-7. }\end{array}$ & $\begin{array}{l}\text { Assessed the transition } \\
\text { from acute to chronic } \\
\text { tinnitus, as well as va- } \\
\text { riables such as anxiety } \\
\text { and depression. }\end{array}$ & $\begin{array}{l}\text { Scores for the assessment of depression and } \\
\text { anxiety in patients with acute tinnitus were si- } \\
\text { milar to those found in patients with chronic } \\
\text { tinnitus; higher levels of depression around } \\
\text { the onset of tinnitus resulted in the distinction } \\
\text { between problematic and non-problematic tin- } \\
\text { nitus and the scores remained high while the } \\
\text { research lasted. }\end{array}$ \\
\hline
\end{tabular}




\begin{tabular}{|c|c|c|c|c|c|}
\hline $\begin{array}{l}\text { Author and } \\
\text { year }\end{array}$ & Type of study & Sample & $\begin{array}{c}\text { Assessment } \\
\text { instruments* }\end{array}$ & Objective & Main results \\
\hline $\begin{array}{l}\text { Kim et al. } \\
(2015)^{22}\end{array}$ & $\begin{array}{l}\text { Cross- } \\
\text { sectional }\end{array}$ & $\begin{array}{l}19,290 \text { participants; } \\
\text { age ranging from } 20 \\
\text { to } 98 \text { years; averaging } \\
45.49 \pm 0.21 \text { years. }\end{array}$ & $\begin{array}{l}\text { National health } \\
\text { research } \\
\text { questionnaire }\end{array}$ & $\begin{array}{l}\text { Analyze the prevalen- } \\
\text { ce and the risk factors } \\
\text { associated with tinnitus } \\
\text { such as depression, } \\
\text { among others. }\end{array}$ & $\begin{array}{l}\text { Higher prevalence of tinnitus over the age of } \\
60(25 \%) \text {, increasing with age ( } 85 \text { years }= \\
36 \%) \text {; positive association of the history of } \\
\text { depression with tinnitus (OR }=2.02 \text { ). }\end{array}$ \\
\hline $\begin{array}{l}\text { Strumilla et } \\
\text { al. }(2017)^{23}\end{array}$ & $\begin{array}{l}\text { Cross- } \\
\text { sectional }\end{array}$ & $\begin{array}{l}212 \quad \text { participants, } \\
\text { age } \quad \text { averaging } \\
48.33 \pm 14.02 \text { years, } \\
\text { divided into } 4 \text { age } \\
\text { groups. }\end{array}$ & $\begin{array}{l}\text { HADS-D; } \\
\text { HADS-A; THI } \\
\text { and VAS }\end{array}$ & $\begin{array}{l}\text { Investigate whether } \\
\text { the severity of tinnitus } \\
\text { may be predicted by } \\
\text { the magnitude of the } \\
\text { depressive and anxiety } \\
\text { symptoms and the pa- } \\
\text { tients' profile. }\end{array}$ & $\begin{array}{l}\text { Severity of tinnitus may be predicted by de- } \\
\text { pressive and anxiety symptoms, of which an- } \\
\text { xiety is the most important. Difference found } \\
\text { in the age group of } 50 \text { to } 69 \text { years; women had } \\
\text { significantly higher scores in all scales. }\end{array}$ \\
\hline $\begin{array}{l}\text { Xu et al. } \\
(2016)^{24}\end{array}$ & $\begin{array}{l}\text { Cross- } \\
\text { sectional }\end{array}$ & $\begin{array}{l}543 \text { participants with } \\
\text { subjective tinnitus, } \\
\text { age group from } 11 \text { to } \\
80 \text { years, averaging } \\
44.81 \pm 14.86 \text { years. }\end{array}$ & $\begin{array}{l}\text { THI; } \\
\text { SAS; } \\
\text { SDS. }\end{array}$ & $\begin{array}{l}\text { Investigate the rela- } \\
\text { tionship between the } \\
\text { quality of sleep and } \\
\text { pychiatric disorders, in- } \\
\text { cluding anxiety and de- } \\
\text { pression in patients with } \\
\text { subjective tinnitus. }\end{array}$ & $\begin{array}{l}\text { The severity of tinnitus and the impairment of } \\
\text { sleep seem to be the main risk factors of tin- } \\
\text { nitus accompanied by depression symptoms } \\
(p<0.05) \text {. No significant correlation has been } \\
\text { found between depresson symptoms and age. }\end{array}$ \\
\hline $\begin{array}{l}\text { Al- } \\
\text { Rawashdeh et } \\
\text { al. }(2018)^{25}\end{array}$ & $\begin{array}{l}\text { Cross- } \\
\text { sectional }\end{array}$ & $\begin{array}{l}1,328 \text { particpants } \\
\text { aged from } 18 \text { to } 86 \\
\text { years; divided by age } \\
\text { in four groups. }\end{array}$ & $\begin{array}{l}\text { Self-rating } \\
\text { questionnaire } \\
\text { on tinnitus; } \\
\text { PHQ-9; } \\
\text { GAD-7; }\end{array}$ & $\begin{array}{l}\text { Evaluated different ENT } \\
\text { complaints and their re- } \\
\text { lationship with psycho- } \\
\text { logical symptoms. }\end{array}$ & $\begin{array}{l}\text { The age group from } 30 \text { to } 50 \text { years differed } \\
\text { from the other ones regarding scores for de- } \\
\text { pression and anxiety, as compared to the ge- } \\
\text { neral group. This relationship remained in the } \\
\text { only-tinnitus group; tinnitus was a predictor of } \\
\text { depression, though not of anxiety. }\end{array}$ \\
\hline $\begin{array}{l}\text { Park et al. } \\
(2016)^{26}\end{array}$ & Co-hort & $\begin{array}{l}140 \text { adults with tin- } \\
\text { nitus divided in two } \\
\text { groups: young (20-45 } \\
\text { years) and elderly (65 } \\
\text { years or over). }\end{array}$ & $\begin{array}{l}\text { THI and } \\
\text { BDI. }\end{array}$ & $\begin{array}{l}\text { Explore the differences } \\
\text { in various characteris- } \\
\text { tics related to tinnitus } \\
\text { and psychological as- } \\
\text { pects. }\end{array}$ & $\begin{array}{l}\text { There was no difference for age, gender and } \\
\text { score for depression between the young and } \\
\text { the elderly groups; severity of tinnitus and de- } \\
\text { pressive symptoms have not differed between } \\
\text { the groups. }\end{array}$ \\
\hline $\begin{array}{l}\text { Michikawa et } \\
\text { al. }(2013)^{27}\end{array}$ & $\begin{array}{l}\text { Prospective } \\
\text { Co-hort }\end{array}$ & $\begin{array}{l}535 \text { elderly } \geq 65 \text { ye- } \\
\text { ars of age; divided into } \\
3 \text { age groups without } \\
\text { baseline depressive } \\
\text { symptoms. }\end{array}$ & $\begin{array}{l}\text { Question-naire; } \\
\text { GDS-15. }\end{array}$ & $\begin{array}{l}\text { Clarify whether tinnitus } \\
\text { precedes the develo- } \\
\text { pment of depressive } \\
\text { symptoms in an elderly } \\
\text { ppulation. }\end{array}$ & $\begin{array}{l}\text { After } 2.5 \text { years of follow-up, men with tinni- } \\
\text { tus revealed a significant increase in the risk } \\
\text { of developing depressive symptoms (RR = } \\
2.07 \text { ). } \\
\text { Aging doesn't seem to have an impact on the } \\
\text { results. }\end{array}$ \\
\hline $\begin{array}{l}\text { Loprinzi et al. } \\
(2013)^{28}\end{array}$ & $\begin{array}{l}\text { Cross- } \\
\text { sectional }\end{array}$ & $\begin{array}{l}696 \text { elderly; age } \\
\text { group: } 70 \text { to } 85 \text { years. }\end{array}$ & $\begin{array}{l}\text { National health } \\
\text { research } \\
\text { question-naire; } \\
\text { PHQ-9. }\end{array}$ & $\begin{array}{l}\text { Verify the association } \\
\text { between tinnitus and de- } \\
\text { pression in the elderly. }\end{array}$ & $\begin{array}{l}\text { There was a significant association between } \\
\text { depression and tinnitus, which suggests that } \\
\text { those that perceived their tinnitus as a mode- } \\
\text { rate problem had greater probability of being } \\
\text { depressed, as compared to those who consi- } \\
\text { dered it to be small or absent. }\end{array}$ \\
\hline
\end{tabular}

*THI (Tinnitus Handicap Inventory); STRAIT (State-Trait Anxiety Inventory-1); BDI (Inventory Beck Depression); HRQoL (Questionnaire health-related quality of life); HADS-D (Hospital Anxiety and Depression Scale); HADS-A (Hospital Anxiety and Depression Scale (HADS) ; VAS (Visual Analogue Escale); Mini-TQ12 (Tinnitus Questionnaire); PHQ9 (Patient Health Questionnaire-9); GAD-7 (Generalized Anxiety Disorder 7-item); SAS (Self-rating Anxiety Scale); SDS (Selfrating Depression Scale); GDS-15 (Geriatric Depression Scale-15 item).

Figure 1. Characteristics of the studies included. 
For the evaluation of tinnitus, depression and anxiety, the most frequently mentioned instruments were, respectively: the Tinnitus Handicap Inventory (THI) 19,20,23,24,26; the Beck Depression Inventory (BDI) 18,19,26; the Patient Health Questionnaire-9 (PHQ9) $21,25,28$; and the Generalized Anxiety Disorder 7-item (GAD-7) ${ }^{21,25}$.

Of the 11 selected studies, 4 included elderly in their sample but not only them ${ }^{18-21}$. Some of these studies were carried out with Brazilian samples, which may be why the papers presented the variables only in the general group; 5 articles reported their data comparing adults and the elderly ${ }^{22-26}$; and finally, only 2 studies ${ }^{27,28}$ evaluated the relationship between variables only in the elderly population.

Regarding the type of tinnitus, 8 papers did not specify the type of tinnitus evaluated 18,20,22,23,25-28. Participants answered questions such as "Do you have tinnitus?"; "Have you heard buzzing, humming, roaring or whistling sounds without an external acoustic source in the last year?"; "What about in the last three months?". If so, the participant was taken into account for the study; 1 study assessed chronic tinnitus ${ }^{19}, 1$ study reported acute tinnitus ${ }^{21}$ and 1 reported subjective tinnitus ${ }^{24}$.

Of those that included the elderly in their general sample, a study with the American population ${ }^{18}$ aiming at quantifying the relationship between tinnitus, anxiety and depression evaluated about 21 million adults over 18 years of age who reported tinnitus in the previous 12 months. There was a significantly higher prevalence of depression $(25.6 \%)$ and anxiety $(26.1 \%)$ among participants reporting tinnitus $(p<0.001)$. In addition, the data revealed that those who reported tinnitus symptoms as a "big problem," or a "very big problem," were 4 to 6 times more likely to have anxiety symptoms (odds ratio $=5.69, p<0.001$ ), or depression (OR: 4.85; $p<0.001$ ) when compared to those without tinnitus or to those for whom tinnitus "was not a big problem." However, the authors did not report whether there was a difference by age group.

Another study ${ }^{20}$ evaluating 208 patients with tinnitus assessed the associations between tinnitus, tinnitus severity, quality of life and depressive symptoms. The findings showed that patients with lower scores for tinnitus severity also reported lower scores on the depression scale $(p<0.001)$. Quality of life was significantly lower and depressive symptoms significantly higher in relation to the general population; the severity of tinnitus (measured by THI sum score) was associated with poorer quality of life and more depressive symptoms $(p<0.001)$. Thus, severity of tinnitus was significantly associated with depressive symptoms and poorer quality of life.

When investigating 57 patients with acute tinnitus and their chronification process, with a follow-up period of one year, evaluating the participants at four different moments, a study ${ }^{21}$ found that $90 \%$ of the participants developed chronic tinnitus. At the beginning of the study, they were allocated in two groups: "low level of depression" and "higher levels of depression". The results demonstrated that a high level of depression around the onset of tinnitus generated a distinction between problematic and non-problematic tinnitus at the end of follow-up $(p<0.05)$. Tinnitus symptoms were lower and significantly reduced during the time of the study in the "low depression" group, while the scores remained unchanged for the "higher depression" group ( $p<0.05)$. As it can be noticed, since the onset of tinnitus there had already been mediation of the psychological symptoms that directly impacted its perception and severity.

In a study ${ }^{19}$ with 81 participants aiming at investigating the performance of psychological mediators intended for the perception of chronic tinnitus, there has been found a moderate to large effect size for positive association between anxiety and tinnitus by which anxiety predicts tinnitus and tinnitus predicts anxiety, generating a vicious cycle ( $r s=0.43, p<0.001$ ). When depression symptoms were included in the regression models, the vicious cycle was no longer present, meaning that depression fully explains the relationship between tinnitus and anxiety $(b=0.79, p<0.001)$.

Regarding studies comparing adults and elderly, interesting findings should be mentioned. A populationbased Korean study ${ }^{22}$ interviewed 19,290 participants, of which $4,234(20.7 \%)$ reported tinnitus in the previous 12 months. Participants were divided by age group differing 5 years one from the other. The prevalence of tinnitus increased with age; it was around $20 \%$ for individuals under 50 years of age, while the highest prevalence was found in the 85-year-old age group (36\%). Aging (every 10 years) increased the odds ratio (OR) of annoying tinnitus by 1.17 times. The female gender was significantly associated with tinnitus (OR $=1.32$ ). The history of depression was positively associated with tinnitus after logistic regression (OR $=2.02$ ). Thus, the authors report that tinnitus may precede depression. Along with that, the rate of tinnitus described as uncomfortable among subjects was 
$30.9 \%$. This proportion increased with age and the rate was $>40 \%$ for individuals over 60 years of age. The authors report that adaptation plays a major role in the discomfort caused by tinnitus. It is possible that older individuals have more difficulty adapting to tinnitus and this difficulty is influenced by psychological factors.

Contrasting with the previous findings, a study ${ }^{23}$ with 212 participants divided into four age groups investigated whether the severity of tinnitus predicts the magnitude of depressive and anxiety symptoms and the patient's profile. Women scored significantly higher on the VAS, THI, HAD-D, and HAD-A scales ( $p<0.01$ ). As for anxiety, it was found to be a strong predictor of tinnitus severity and differences between the genders could be at least partially based on this, since the largest difference was found in the age group of 30 to 49 years, when women seek to balance professional and family life. Post hoc age analyses demonstrated differences in THI scores between the 50-to-69-year group and the $>70$-year group ( $p=0.01$ ); and in the $<29$ years and 50-to-69-year groups $(p=0.03)$. The 50 -to-69-year group differed significantly from the $<29$ and 30-to-49-year groups in the VAS score $(p<0.01)$. Significant differences were also found in the scores of the depression scale used (HAD-D) between the $<29$ and 30-to-49-year groups ( $p=0.09$ ); as well as between $<29$ and 50-to-69-year groups $(p=0.02$ ). The authors point to a directly proportional increase between the values of the scales and the increase of the age range (HAD-D up to 50-69 years $=6.90$ ), however, after 70 years old there was a considerable decrease (HAD-D 70+ $=3.91$ ). The authors report that the elderly may become accustomed to their condition and this would contribute to a lesser impact on the perception of tinnitus.

$\mathrm{Xu}$ et al. ${ }^{24}$, after evaluating 543 participants with tinnitus and the relationship between quality of sleep and psychiatric disorders, including anxiety and depression, found that $12.9 \%$ of the participants had symptoms of anxiety, $18.0 \%$ presented depression, $8.66 \%$ had anxiety and depression, $4.23 \%$ showed only anxiety, $9.39 \%$ showed only depression. The logistic regression analysis revealed that acute tinnitus ( $<3$ months), younger age group, hearing loss, sleep impairment and tinnitus severity were the main risk factors for tinnitus with anxiety symptoms $(p<0.05)$. The severity of tinnitus assessed by $\mathrm{THI}$ is strongly related to the scores of the anxiety and depression scales, regardless of age $(p<0.001)$. There was no correlation between anxiety symptoms and gender.
Severity of tinnitus and sleep impairment seem to be the major risk factors for tinnitus accompanied by depression symptoms $(p<0.05)$. No significant correlation was found between depression symptoms, gender and age. The study suggested that young people are more likely to develop anxiety symptoms because they tend to be more easily surprised by the sudden onset of tinnitus, leading to anxiety.

However, the authors ${ }^{26}$ compared the characteristics related to tinnitus and psychological aspects of 140 adults divided into two groups: younger adults (ages between 20 and 45 years) and the elderly (65 years or older). There was no statistical difference between the scores on the depression scale, being that the proportion of low depression was similar in the groups (53\% and $55 \%$, respectively). There was also no difference for THI categories. These results indicate that depressive symptoms are associated with tinnitus in adults of all ages.

Another study ${ }^{25}$ that evaluated the impact of anxiety and depression on 1,328 subjects with different ENT complaints, but analyzing tinnitus separately, divided the sample into four groups according to their age: $<30,30$ to 50,51 to 70 and $>70$ years. In the general group, the post-hoc analysis showed a difference in the score for the depression scale in the age group of 30 to 50 years as superior to the $<30$-, 51-to-70and $>70$-year groups $(p=0.029, p=0.001$ and $p=$ 0.007 , respectively). Likewise, a difference was found for the scores of the anxiety scale for the age group of 30 to 50 years, which was higher than the $<30$-, 51-to-70- and $>70$-year groups ( $p<0.005, p<0.005$, $p=0.001$, respectively). In the specific tinnitus group this relationship was maintained and the scores on the depression scale were statistically significant $(p=$ 0.002). In addition, higher scores on the anxiety scale were statistically significant in the tinnitus group ( $p=$ 0.019). Tinnitus was demonstrated as a significant predictor of depression $(O R=2.71)$, as well as a predictor of severe depression $(\mathrm{OR}=3.67)$. As for anxiety, tinnitus was not a predictor. Thus, in this study, the age range of 30 to 50 years differed significantly from the others.

As previously mentioned, only two studies evaluated the relationship between the highlighted variables in an elderly population. A prospective cohort study ${ }^{27}$ evaluating 535 elderly people 65 years of age and older, without baseline depression, sought to clarify whether tinnitus precedes the development of depressive symptoms in an elderly population. During the 2.5 -year 
follow-up period in the cumulative period, the incidence of depressive symptoms was $20.5 \%$ among men with tinnitus, and $9.5 \%$ among those without tinnitus. Men with tinnitus had a statistically significant increase in the risk of depressive symptoms $(\mathrm{RR}=2.07,95 \% \mathrm{Cl}$ $=1.01-4.25)$, which persisted after adjustments. On the other hand, no association between tinnitus and depressive symptoms was observed in women. The authors suggest that persistent (chronic) tinnitus is more common in men because of hearing impairment caused by occupational noise exposure which can lead to depressive symptoms.

Authors $^{28}$ evaluated 696 elderly aged from 70 to 85 years to verify the association between tinnitus and depression in the elderly. The results demonstrated positive association between depression and tinnitus in those individuals who reported tinnitus at least as a moderate problem. This suggests that those who perceived tinnitus as a moderate problem were more likely to be depressed than those who perceived it as a small problem or as no problem at all (beta coefficient: 1.28, 95\% Cl: 0.26-2.29, $\mathrm{p}<0.01$ ).

In conclusion, the studies indicated a probable association between the variables taken into consideration. There has been shown a tendency that, as age increases, so do the scores. Regarding this, two studies found that the adult age group around 50 years old differed from the others; one study found difference for the elderly group; and one study did not find differences between the age groups. This, therefore, makes evident the lack of literature on these issues when related to the elderly population.

It was, thus, evidenced that the relationship between the variables is extremely complex, highly dependent on the ability of each individual to deal with adversities, and affects men and women of all ages. Health professionals should always be attentive to the psychological symptoms of their patients, once it's important to track these disorders. Authors ${ }^{29}$ suggest the importance of a multiprofessional effort to establish the treatment procedure for patients with tinnitus. Psychological and psychiatric evaluation is recommended in patients who present a Tinnitus Handicap Inventory (THI) score above 36 in order to improve their quality of life.

Such increase in changes as the person ages, as it has been observed in the studies, especially as those that approached only the elderly population are compared to those that approached both the elderly and the adult population, supports the need for new studies. This is mainly due to the fact that this popualtion constitutes a risk group for both tinnitus and the psychological changes that may arise as a result of it.

\section{CONCLUSION}

This study has made possible to notice a lack of studies when taking into account the association of tinnitus with anxiety and depression in the elderly. It has also allowed carrying out a comparison that showed the increase of these changes as age increases. A probable association of tinnitus with anxiety and depression in adults and the elderly, for both genders, has been found, as well as the contribution of aging to the severity of tinnitus and related psychological symptoms, affecting the quality of life of these people.

Further studies are necessary to confirm the actual association between tinnitus, anxiety and depression in the elderly, with the purpose of assisting future interventions, which would both promote mental health and prevent these aspects related to tinnitus. Consideration should also be given to the development of public policies focused on anxiety and depression as risk factors for tinnitus as well as for other symptoms that affect the quality of life of the elderly.

\section{REFERENCES}

1. Baguley D, McFerran D, Hall D. Tinnitus. Lancet. 2013;382(9904):1600-7.

2. Teixeira A, Lessa A, Rosito L, Neves C, Bueno C, Picinini $T$ et al. Influence of factors and personal habits on the tinnitus perception. Rev. CEFAC. 2016;18(6):1310-5.

3. Baigi A, Oden A, Almlid-Larsen V, Barrenäs ML, Holgers KM. Tinnitus in the general population with a focus on noise and stress: a public health study. Ear Hear. 2011;32(6):787-9.

4. Oiticica J, Bittar RSM. Tinnitus prevalence in the city of São Paulo. Braz J Otorhinolaryngol. 2015;81(2):167-76.

5. Pinto PCL, Sanchez TG, Tomita S. Avaliação da relação entre severidade do zumbido e perda auditiva, sexo e idade do paciente. Braz J Otorhinolaryngol. 2010;76(1):18-24.

6. Moreira MD, Marchiori LLM, Costa VdSP, Damasceno EC, Gibrin PCD. Tinnitus: probable association with the elderly's cervical alterations. Int arch otorhinolaryngol. 2011;15(3):333-7. 
7. Gibrin PCD, Melo JJ, Marchiori LLM. Prevalence of tinnitus complaints and probable association with hearing loss, diabetes mellitus and hypertension in elderly. CoDAS. 2013;25(2):176-80.

8. Sanchez TG, Ferrari G. O que é zumbido? In: Samelli AG ( ed). Zumbido: avaliação, diagnóstico e reabilitação: abordagens atuais. São Paulo: Lovise; 2004. p. 17-22.

9. Abelha L. Depressão, uma questão de saúde pública. Cad Saude Colet. 2014;22(3):223.

10. Allen AJ, Leonard H, Swedo SE. Current knowledge of medications for the treatment of childhood anxiety disorders. Am Acad Child Adolesc Psychiatry. 1995;34(8):976-86.

11. Branco-Barreiro FCA, Aprile MR, Peluso E, Scharlach R, Onishic E, Meira M. Orientação ao paciente com zumbido como parte do processo de intervenção. In: Marchiori LLdM (ed). Equilíbrio humano e seus distúrbios: do estilo de vida à reabilitação. Londrina: Unopar; 2015. p. 215-23.

12. Geocze L, Mucci S, Abranches DC, Marco MA, Penido NO. Revisão sistemática sobre as evidências de associação entre zumbido e depressão. Braz J Otorhinolaryngol. 2013;79(1):106-11.

13. Pattyn T, Van Den Eede F, Vanneste S, Cassiers L, Veltman DJ, Van De Heyning $P$ et al. Tinnitus and anxiety disorders: a review. Hearing research. 2016;333:255-65.

14. Ziai K, Moshtaghi O, Mahboubi H, Djalilian HR. Tinnitus patients suffering from anxiety and depression: a review. Int Tinnitus $\mathrm{J}$. 2017;21(1):68-73.

15. Berwanger O, Suzumura EA, Buehler AM, Oliveira JB. Como avaliar criticamente revisões sistemáticas e metanálises. Rev Bras Ter Intensiva. 2007;19(4):475-80.

16. Braga M, Melo M. Como fazer uma revisão baseada na evidência. Rev Port Clin Geral. 2009;25(6):660-6.

17. National Heart, Lung and Blood Institute. Quality assessment tool for observational cohort and cross-sectional studies. 2014. Avalible from: https://www.nhlbi.nih.gov/health-topics/ study-quality-assessment-tools

18. Bhatt JM, Bhattacharyya N, Lin HW. Relationships between tinnitus and the prevalence of anxiety and depression. Laryngoscope. 2017;127(2):466-9.

19. Trevis KJ, McLachlan NM, Wilson SJ. Psychological mediators of chronic tinnitus: the critical role of depression. J Affect Disord. 2016;204:234-40.
20. Weidt S, Delsignore A, Meyer M, Rufer M, Peter N, Drabe $\mathrm{N}$ et al. Which tinnitus-related characteristics affect current health-related quality of life and depression? A cross-sectional cohort study. Psychiatry Res. 2016;237:114-21.

21. Walhäusser-Franke E, D'Amelio R, Glauner A, Delb W, Servais JJ, Hörmann $K$ et al. Transition from acute to chronic tinnitus: predictors for the development of chronic distressing tinnitus. Front Neurol. 2017;8(605):1-13.

22. Kim H-J, Lee H-J, An SY, Sim S, Park B, Kim SW et al. Analysis of the prevalence and associated risk factors of tinnitus in adults. PLoS One. 2015;10(5):e0127578.

23. Strumila R, Lengvenyte A, Vainutiene V, Lesinskas E. Influence of personality traits on tinnitus severity perception, anxiety and depressive symptoms. PsychiatrQ. 2017;88(4):865-77.

24. Xu Y, Yao J, Zhang Z, Wang W. Association between sleep quality and psychiatric disorders in patients with subjective tinnitus in China. Eur Arch Otorhinolaryngol. 2016;273(10):3063-72.

25. Al-Rawashdeh BM, Saleh MYN, Mustafa RB, Alkhouja MF, Elkhatib AH, Sughaireen $H$ et al. Prevalence of depression and anxiety among otolaryngology outpatients at Jordan University Hospital. Perspect Psychiatr Care. 2018;1-13. doi: 10.1111/ppc.12320. [Epub ahead of print].

26. Park SY, Han JJ, Hwang JH, Whang ES, Yeo SW, Park SN. Comparison of tinnitus and psychological aspects between the younger and older adult patients with tinnitus. Auris Nasus Larynx. 2017;44(2):147-51.

27. Michikawa T, Nishiwaki $Y$, Saito $H$, Mizutari $K$, Takebayashi T. Tinnitus preceded depressive symptoms in community-dwelling older Japanese: a prospective cohort study. Prev med. 2013;56(5):333-6.

28. Loprinzi PD, Maskalick S, Brown K, Gilham B. Association between depression and tinnitus in a nationally representative sample of US older adults. Aging Ment Health. 2013;17(6):714-7.

29. Salviati M, Macrì F, Terlizzi S, Melcore C, Provenzano A, Capparelli E et al. The Tinnitus Handicap Inventory as a screening test for psychiatric comorbidity in patients with tinnitus. Psychosomatics. 2013;54(3):248-56. 